\title{
Glioma Associated Stem Cells (GASCs) Isolation and Culture
}

Evgenia Bourkoula ${ }^{1}$, Damiano Mangoni ${ }^{1}$, Federica Caponnetto ${ }^{1}$, Tamara $_{\text {lus }}^{2}$, Miran Skrap ${ }^{2}$, Antonio Paolo Beltrami ${ }^{1}$ and Daniela Cesselli ${ }^{\star}$

${ }^{1}$ Department of Medical and Biological Sciences, University of Udine, Udine, Italy; ${ }^{2}$ Department of Neurosurgery, University Hospital of Udine, Udine, Italy *For correspondence: daniela.cesselli@uniud.it

[Abstract] Glioma Associated Stem Cells (GASCs) represent a population of nontumorigenic multipotent stem cells hosted in the microenvironment of human gliomas. In vitro, these cells are able, through the release of exosomes, to increase the biological aggressiveness of glioma-initiating cells. The clinical importance of this finding is supported by the strong prognostic value associated with the GASCs surface immunophenotype thus suggesting that this patient-based approach can provide a groundbreaking method to predict prognosis and to exploit novel strategies that target the tumor stroma (Bourkoula et al., 2014).

\section{Materials and Reagents}

1. Hank's balanced salt solution (HBSS) without calcium and magnesium (SigmaAldrich, catalog number: $\mathrm{H} 2387$ )

2. Collagenase type II (Sigma-Aldrich, catalog number: C6885-500MG)

3. Fetal bovine serum (FBS) (EuroClone, catalog number: ECS0180L)

4. Trypan blue (Sigma-Aldrich, catalog number T6146-5G)

5. Dulbecco's phosphate buffered saline (D-PBS) (Life Technologies, catalog number: 14190-250)

6. Fibronectin from human plasma $0.1 \%$ solution (cell culture tested) (Sigma-Aldrich, catalog number: F0895)

7. Modified Eagle's medium (MEM) Joklik without $\mathrm{NaHCO}_{3}$ (Sigma-Aldrich, catalog number: M0518)

8. Hepes (powder) (Sigma-Aldrich, catalog number: H3375)

9. L-glutamine (Sigma-Aldrich, catalog number: G7513)

10. Taurine (Sigma-Aldrich, catalog number: T0625)

11. Penicillin-streptomycin (100x solution stabilized, sterile-filtered, suitable for cell culture) (Sigma-Aldrich, catalog number: P4333-100ML)

12. Insulin (Sigma-Aldrich, catalog number: I5523-50MG)

13. Dulbecco's modified Eagle's medium (DMEM) low glucose (Life Technologies, Gibco ${ }^{\circledR}$, catalog number: 31600-091)

14. MCDB-201 (Sigma-Aldrich, catalog number: M6770)

15. Linoleic acid-bovine serum albumin (BSA) (Sigma-Aldrich, catalog number: L9530) 


\section{bĭo-protocol}

16. Dexamethasone (powder) (Sigma-Aldrich, catalog number: D2915)

17. Ascorbic acid-2 phosphate (powder) (Sigma-Aldrich, catalog number: A8960)

18. 100x insulin-transferrin-selenium (ITS) (Life Technologies, Gibco ${ }^{\circledR}$, catalog number: 41400-045)

19. Stem cell tested fetal bovine serum (Stem Cells Technologies, catalog number: 10M37180)

20. Human platelet derived growth factor-BB (hPDGF-BB) (Pepro Tech, catalog number: 100-14B)

21. Human epidermal growth factor (hEGF) (Pepro Tech, catalog number: AF-100-15)

22. TrypLE-express dissociation reagent (Life Technologies, Gibco ${ }^{\circledR}$, catalog number: 12605)

23. Basic buffer (BB) (see Recipes)

24. Incubation buffer (IB) (see Recipes)

25. $0.025 \%$ Collagenase type II (see Recipes)

26. $0.4 \%$ Trypan blue solution (see Recipes)

27. Fibronectin-coated $100 \mathrm{~mm}$ petri dish (see Recipes)

28. Multipotent adult stem cell (MASC) medium (see Recipes)

\section{Equipment}

1. Sterile tissue culture dishes $100 \times 20$ mm style (BD Biosciences, Falcon ${ }^{\circledR}$, catalog number: 353003)

2. Scalpel blades (Sigma-Aldrich, catalog number 27046)

3. Sterile serological transfer pipettes

4. Serological pipettes

5. Sterile Falcon tubes

6. Mesh filter $(70 \mu \mathrm{m})\left(\mathrm{BD}\right.$ Biosciences, Falcon ${ }^{\circledR}$, catalog number 352350$)$

7. Biological hood (Faster, model: Safe FAST Elite)

8. Agitation rotor (Celbio, model: MINI OVEN)

9. Burker counting chamber (Sigma-Aldrich, catalog number: Z359629-1EA)

10. $37^{\circ} \mathrm{C}, 5 \% \mathrm{CO}_{2}, 5 \% \mathrm{O}_{2}$ force air incubator (New Brunswick, model: Galaxy $170 \mathrm{R}$ )

11. Centrifuge (Heraeus Instruments, model: Megafuge 1.0 R)

12. Light microscope (Leica Microsystems, model: DMIL)

\section{Procedure}

A. Isolation and primary culture of primitive cells from human glioma (see Video 1)

1. Under biological hood, place the glioma sample into sterile $100 \mathrm{~mm}$ Petri dish and cut the fragments into $\sim 1 \mathrm{~mm}$ pieces using scalpels.

2. Re-suspend glioma fragments into $3-5 \mathrm{ml}$ of $\mathrm{BB}$ and transfer them into a $15 \mathrm{ml}$ Falcon 
tube.

3. Let the fragments deposit to the bottom of the $15 \mathrm{ml}$ Falcon tube by gravity at room temperature. If fragments will not deposit into the bottom, centrifuge the suspension at $300 \times g$ for $1 \mathrm{~min}$.

4. Remove the supernatant and re-suspend the volume of the pellet in an equal volume of collagenase solution $(0.025 \%)$.

5. Incubate the suspension for $5 \mathrm{~min}$ in an agitation rotor at $37^{\circ} \mathrm{C}$.

6. At the end of the incubation period, gently shake the bottom of the Falcon tube and add $5 \mathrm{ml}$ of IB and gently pipette it with a $10 \mathrm{ml}$ serological pipette for 4-5 min.

7. Pre-wet a $70 \mu \mathrm{m}$ mesh filter by filtering $5 \mathrm{ml}$ of sterile, fresh HBSS using a $5 \mathrm{ml}$ sterile serological pipette into a $50 \mathrm{ml}$ Falcon tube.

8. Filter the cell suspension through the pre-wet $70 \mu \mathrm{m}$ mesh filter.

9. Centrifuge the filtered suspension at $500 \times \mathrm{g}$ for $5 \mathrm{~min}$ at room temperature and resuspend it into $1 \mathrm{ml}$ of MASC medium.

10. Count the cells using the Burker Counting chamber: Remove $10 \mu$ of cell suspension, mix it with an equal volume of $0.4 \%$ Trypan blue in D-PBS and apply $10 \mu \mathrm{l}$ of diluted cells to the Burker chamber. Count at least four squares and calculate the number of cells by multiplying the medium value obtained for $2 \times 10^{4}$. You will obtain the total amount of cells $/ \mathrm{ml}$ of cell suspension.

11. Seed 5,000 cells $/ \mathrm{cm}^{2}$ into fibronectin-coated dishes and culture them in MASC medium at $37{ }^{\circ} \mathrm{C}$ in a $5 \% \mathrm{CO}_{2}, 5 \% \mathrm{O}_{2}$ force air incubator.

B. Sub-culture of glioma associated stem cells (GASCs)

1. Take out from the incubator $\left(5 \% \mathrm{CO}_{2}, 5 \% \mathrm{O}_{2}\right.$, at $\left.37^{\circ} \mathrm{C}\right)$ the dish containing the cells that has to be split. Check at the microscope that cells have reached $80 \%$ of confluence (7-10 days after seeding).

2. Transfer the dish below the biological hood, open the dish and discard the supernatant with a $10 \mathrm{ml}$ sterile serological pipette.

3. Add $5 \mathrm{ml}$ of HBSS or D-PBS to the dish, gently move the plate in order to cover the entire surface, and then remove the HBSS or D-PBS. Repeat the washing procedure. Remove carefully the HBSS or D-PBS.

4. Add $2 \mathrm{ml}$ of TrypLE Express solution for each dish. Since cells will detach very fast, check continuously at the microscope the process in order to avoid over-digestion.

5. When cells are finally detached, add $5 \mathrm{ml}$ of HBSS or D-PBS to dilute the TrypLE Express solution.

6. Re-suspend the cells by gently pipetting them through a $10 \mathrm{ml}$ sterile serological pipette. To recover all cells from the dishes, wash the Petri dish one more time, by adding $3 \mathrm{ml}$ of fresh sterile HBSS or D-PBS and put the solution in the Falcon Tube containing the previous obtained cell suspension.

7. Centrifuge the cell suspension at $500 \times g$ for $5 \mathrm{~min}$ at room temperature, discard the 


\section{bio-protocol}

supernatant and re-suspend the cell pellet in $1 \mathrm{ml}$ of MASC medium.

8. Seed the cells onto fibronectin-coated dishes at the concentration of $3,500 \mathrm{cells} / \mathrm{cm}^{2}$.

9. Change the medium every three days. Split the cells when they will reach $80 \%$ confluence.

\section{Representative data}

Video 1. GASC isolation procedure. Video 1 is representing the steps from 1 to 11 of the GASCs isolation protocol.
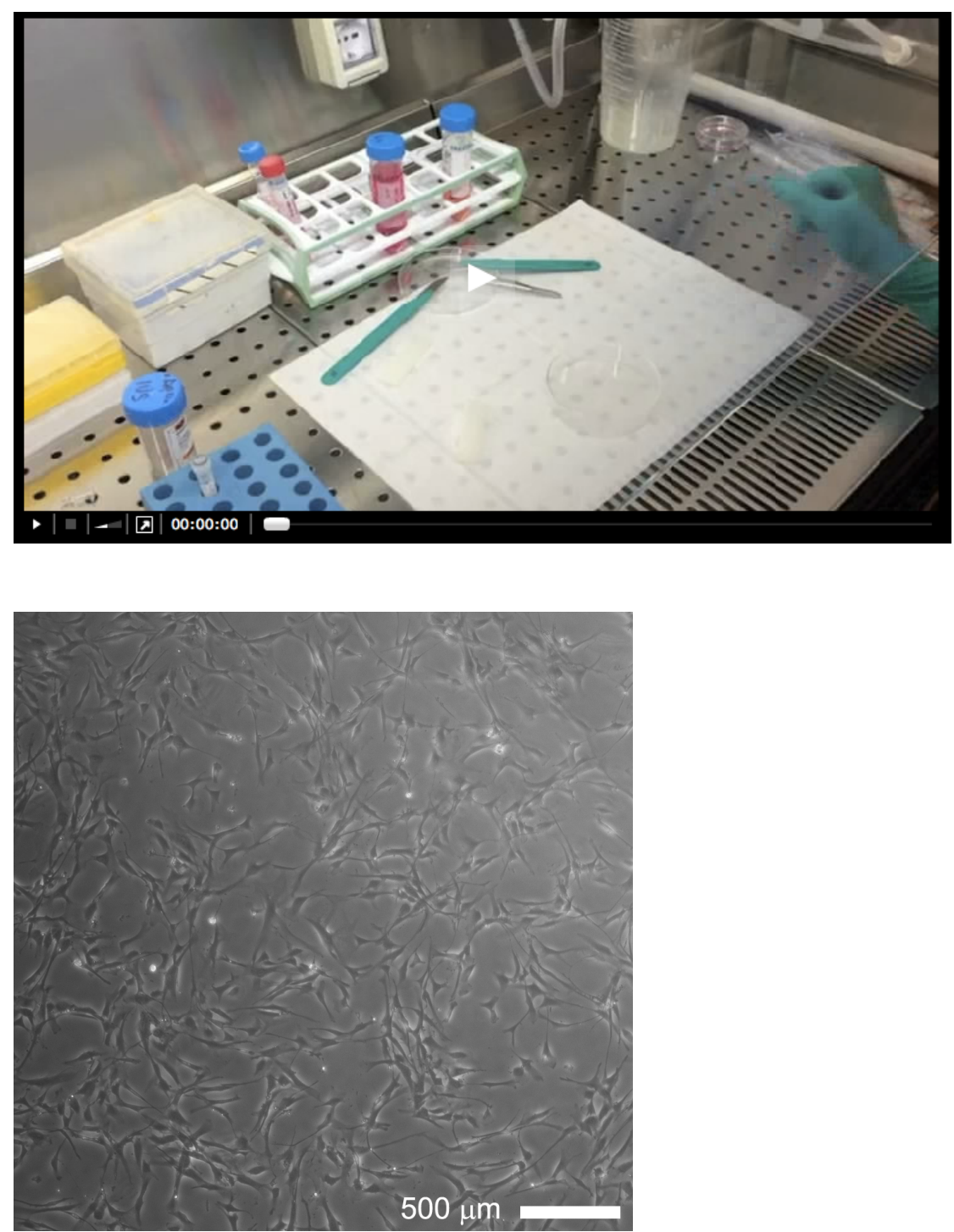

Figure 1. Phase contrast image of GASCs at the third passage in culture

\section{Recipes}

1. Basic buffer (BB)

$11 \mathrm{~g} \mathrm{MEM} \mathrm{Joklik} \mathrm{without} \mathrm{NaHCO}_{3}$ (powder)

$4.7 \mathrm{~g}$ Hepes (powder) 
$0.3 \mathrm{~g}$ L-glutamine

$0.25 \mathrm{~g}$ taurine

$5 \mathrm{ml}$ penicillin-streptomycin

Insulin $20 \mathrm{U} / \mathrm{L}$

Add non-pyrogenic $\mathrm{dH}_{2} \mathrm{O}$ up to $900 \mathrm{ml}$ and adjust the $\mathrm{pH}$ to 7.3

Add non-pyrogenic $\mathrm{dH}_{2} \mathrm{O}$ up to $1,000 \mathrm{ml}$ and filter sterilize $(0.2 \mu \mathrm{m})$

Stored at $4{ }^{\circ} \mathrm{C}$

2. Incubation buffer (IB)

Add $10 \%$ of fetal bovine serum to HBSS

Stored at $4{ }^{\circ} \mathrm{C}$

3. $0.025 \%$ Collagenase type II

$0.025 \mathrm{~g}$ Collagenase type II

Add $10 \mathrm{ml}$ of BB and carefully pipette for 2-3 min

Add BB up to $100 \mathrm{ml}$, filter sterilize and stored at $-20{ }^{\circ} \mathrm{C}$

4. $0.4 \%$ Trypan blue solution

$0.1 \mathrm{~g}$ Trypan blue

Add $25 \mathrm{ml}$ sterile $1 \times$ D-PBS

Vortex and stored at room temperature

5. Fibronectin-coated $100 \mathrm{~mm}$ petri dish

For each $100 \mathrm{~mm}$ petri dish, add $5 \mu \mathrm{l} 0.1 \%$ fibronectin in $1 \mathrm{ml}$ of HBSS

Carefully cover the bottom of the dish with the fibronectin solution and keep for at least $20 \mathrm{~min}$ at room temperature

Remove the exceeding solution from the dish

6. Multipotent adult stem cell (MASC) medium

Base medium (60\% DMEM low glucose $+40 \%$ MCDB-201)

$2 \%$ stem cell tested fetal bovine serum

$10 \mathrm{ng} / \mathrm{ml}$ hPDGF-BB

$10 \mathrm{ng} / \mathrm{ml} \mathrm{hEGF}$

$1 \mathrm{mg} / \mathrm{ml}$ linoleic acid-BSA

$10^{-9} \mathrm{M}$ dexamethasone

$1 \mathrm{x}$ ITS $100 \mathrm{x}$

$10^{-4} \mathrm{M}$ ascorbic acid-2 phosphate

1x penicillin-streptomycin 100x

Adjust the $\mathrm{pH}$ to 7.3

Filter sterilize $(0.2 \mu \mathrm{m})$ and stored at $4{ }^{\circ} \mathrm{C}$

\section{Acknowledgments}

FIRB Accordi di programma 2011 Pr. RBAP11Z4Z9. FIRB accordi di programma 2011 Pr. RBAP11ETKA_007. Programma per la Cooperazione Transfrontaliera Italia-Slovenia 


\section{bĭo-protocol}

2007-2013. Title: "Identificazione di nuovi marcatori di cellule staminali tumorali a scopo diagnostico e terapeutico"; AIRC 5 per mille Special program 2011, Pr. 12214. Project ERC- 7FP SP 2 IDEAS QUIDPROQUO G.A. n. 269051. The protocol was adopted from Bourkoula et al. (2014).

\section{References}

1. Andolfi, L., Bourkoula, E., Migliorini, E., Palma, A., Pucer, A., Skrap, M., Scoles, G., Beltrami, A. P., Cesselli, D. and Lazzarino, M. (2014). Investigation of adhesion and mechanical properties of human glioma cells by single cell force spectroscopy and atomic force microscopy. PLoS One 9(11): e112582.

2. Beltrami, A. P., Cesselli, D., Bergamin, N., Marcon, P., Rigo, S., Puppato, E., D'Aurizio, F., Verardo, R., Piazza, S. and Pignatelli, A. (2007). Multipotent cells can be generated in vitro from several adult human organs (heart, liver, and bone marrow). Blood 110(9): 3438-3446.

3. Bourkoula, E., Mangoni, D., lus, T., Pucer, A., Isola, M., Musiello, D., Marzinotto, S., Toffoletto, B., Sorrentino, M., Palma, A., Caponnetto, F., Gregoraci, G., Vindigni, M., Pizzolitto, S., Falconieri, G., De Maglio, G., Pecile, V., Ruaro, M. E., Gri, G., Parisse, P., Casalis, L., Scoles, G., Skrap, M., Beltrami, C. A., Beltrami, A. P. and Cesselli, D. (2014). Glioma-associated stem cells: a novel class of tumor-supporting cells able to predict prognosis of human low-grade gliomas. Stem Cells 32(5): 1239-1253. 